\title{
Perceptions of challenges to subsistence agriculture, and crop foraging by wildlife and chimpanzees Pan troglodytes verus in unprotected areas in Sierra Leone
}

\author{
Rosa M. Garriga, Ignasi Marco, Encarna Casas-Díaz \\ Bala Amarasekaran and Tatyana Humle
}

\begin{abstract}
The 2009-2010 Sierra Leone National Chimpanzee Census Project estimated there was a population of 5,580 chimpanzees Pan troglodytes verus distributed across the country, with $>50 \%$ occurring outside protected areas. The census also highlighted the significance of competition between people and chimpanzees for resources in areas dominated by farming activities where wild chimpanzees forage on crops. We selected four study areas in two districts in Sierra Leone with high chimpanzee density in habitats dominated by agriculture, far from any protected areas. Our objectives were to assess farmers' perceptions of the main challenges to their agricultural yields, and the wildlife involved in crop foraging, and their perceptions of chimpanzees in particular, as well as the main crop protection measures used. We conducted 257 semi-structured interviews with local farmers across the four study areas. We found that (1) farmers reported wild animals as the main challenge to their agricultural practices; (2) most complaints concerned cane rats Thryonomys swinderianus, which targeted almost all crop types, especially rice and cassava; (3) chimpanzees reportedly targeted 21 of the 23 crop types cultivated, but did so less often than cane rats, focusing particularly on oil palm, cassava and domestic fruits; (4) overall, chimpanzees were not among the top three most destructive animals reported; (5) chimpanzees were generally perceived as being more destructive than dangerous and as having declined since before the civil war; and (6) the main crop protection measure employed was fencing interspersed with traps. Our findings show the importance of investigating farmers' perceptions to inform the development of appropriate conservation strategies aimed at promoting coexistence of people and wildlife in degraded landscapes.
\end{abstract}

Rosa M. Garriga* (Corresponding author) and Ignasi Marco Servei d'Ecopatologia de Fauna Salvatge, Facultat de Veterinària, Universitat Autònoma de Barcelona, Spain. E-mail rosagarriga@yahoo.com

EnCARna Casas-Díaz Departament de Sanitat i Anatomia Animals, Facultat de Veterinària, Universitat Autònoma de Barcelona, Spain

Bala Amarasekaran Tacugama Chimpanzee Sanctuary, Sierra Leone

Tatyana Humle Durrell Institute of Conservation and Ecology, School of Anthropology and Conservation, University of Kent, UK

${ }^{*}$ Also at: Tacugama Chimpanzee Sanctuary, Sierra Leone

Received 22 June 2016. Revision requested 4 August 2016.

Accepted 18 October 2016. First published online 6 April 2017.
Keywords Anthropogenic landscape, chimpanzee, crop-raiding, farming, human-wildlife coexistence, Pan troglodytes verus

\section{Introduction}

Competition for resources between wildlife and people is a widespread concern in places where they coexist (Woodroffe et al., 2005). Wild animals are an important part of the life and diet of many local people in developing countries (Hoffman \& Cawthorn, 2012) but habitat loss, agricultural expansion (Maxwell et al., 2016) and human encroachment into wildlife habitat are key drivers of wildlife population decline and even local extinctions (Van Vliet et al., 2012). In anthropogenic landscapes wildlife may be compelled to consume cultivated foods or prey on domesticated animals to survive (McLennan, 2008; Hockings et al., 2009; Inskip \& Zimmermann, 2009). Competition between wildlife and people is problematic in areas where farmers depend solely or predominantly on subsistence agriculture and natural resources, as it can affect peoples' livelihoods and their relationship with, and perceptions of, wildlife (Naughton-Treves, 1998; Webber \& Hill, 2014; Humle \& Hill, 2016).

Sierra Leone is home to the western chimpanzee Pan troglodytes verus, which is categorized as Critically Endangered on the IUCN Red List (Humle et al., 2016). In Côte d'Ivoire the wild chimpanzee population has declined by up to $90 \%$ in recent years (Campbell et al., 2008) and this highlights the importance of Sierra Leone for chimpanzee conservation in West Africa. However, chimpanzees face serious threats in Sierra Leone, including habitat loss, hunting, and retaliation as a result of competition with people for resources (Brncic et al., 2010). The chimpanzee is protected by law across all range states where it occurs in the wild (Humle et al., 2016). However, the laws protecting the species are often not enforced across most of its range, as evidenced by the continual influx of orphan chimpanzees into sanctuaries or rehabilitation centres, often by-products of bushmeat hunting (Faust et al., 2011) and the persistence of the illegal trade in live individuals (Stiles et al., 2013). Conservation efforts are often focused on protecting areas of high value for 
biodiversity that contain threatened species of international concern. Most studies to date have therefore been carried out in or around protected areas, and comparatively few have investigated sympatry between chimpanzees and farmers in landscapes dominated by agriculture (e.g. Halloran et al., 2013; McLennan \& Hill, 2013; Hockings et al., 2015).

Tacugama Chimpanzee Sanctuary coordinated the Sierra Leone National Chimpanzee Census Project during 20092010. The census estimated a total population of 5,580 chimpanzees (range $3,052-10,446$ ) across the country, with $>50 \%$ located outside protected areas (Brncic et al., 2010). The findings highlighted the extent of human-chimpanzee competition for resources, with $88 \%$ of villages that reported local presence of chimpanzees mentioning that chimpanzees foraged on crops. The population and habitat viability assessment conducted following the census suggested the need for a better understanding of the costs and benefits of coexistence for both people and chimpanzees; the threats faced by chimpanzees in such landscapes; the attitudes and perceptions of the farmers regarding chimpanzees; and how and why these change over time (Carlsen et al., 2012).

Local people who depend on natural resources often perceive conservation efforts to protect biodiversity as a threat to their livelihoods (Redpath et al., 2013; Madden \& McQuinn, 2014). However, not all wildlife causes the same amount of damage and farmers may hold biased perceptions of damage linked to species attributes such as size, temporal and spatial activity patterns, sociality and/or traditional and related cultural taboos and beliefs (Humle \& Hill, 2016). Understanding local perceptions, attitudes and concerns regarding wildlife is crucial for appropriate conservation and management strategies, to reduce conflict and promote a sustainable coexistence between people and wildlife (Redpath et al., 2013; Madden \& McQuinn, 2014). Non-human primates are often cited as one of the main perpetrators of crop raiding in the geographical ranges where they occur (Humle \& Hill, 2016). Foraging on crops by chimpanzees has also been reported across Africa (Hockings \& Humle, 2009; McLennan \& Hockings, 2014). To date, studies have primarily focused on evaluating the crops targeted by chimpanzees and their dietary contribution relative to wild foods (Hockings et al., 2009; Hockings \& McLennan, 2012; McLennan \& Hockings, 2014), as well as chimpanzees' responses to interactions with people and associated infrastructure, such as roads (McLennan \& Hill, 2010, 2012; Hockings, 2011; Cibot et al., 2015; McLennan \& Asiimwe, 2016). Although reports of fatal attacks by chimpanzees on people are rare, there has been an increasing number of accounts of chimpanzees behaving aggressively towards people (McLennan \& Hockings, 2016). Even if often attributable to prior provocation by people (Hockings et al., 2010), such instances can elicit or increase negative attitudes towards chimpanzees, generate resentment and accentuate the fear of attack (McLennan \& Hockings, 2016).
Nevertheless, few studies have explored people's perceptions and attitudes towards chimpanzees. It was found that chimpanzees in Tombali, Guinea-Bissau, were perceived as human-like and inedible but were also considered to be pests because of their crop foraging behaviour (Costa et al., 2013). In this region, non-Muslims appeared to be more tolerant than Muslims, and men perceived chimpanzees more positively than women. In the Budongo forest of Uganda, farmers perceived chimpanzees more positively than other primates, such as baboons Papio spp., although some farmers indicated they were afraid of chimpanzees (Webber \& Hill, 2014). Farmers in Bulindi, Uganda, were found in general to have a positive perception of chimpanzees and tolerate occasional foraging of domestic fruits but not cash crops (McLennan \& Hill, 2012). This latter study emphasized that alterations to the habitat and human encroachment can negatively affect chimpanzee behaviour towards people, thus 'challenging residents' traditionally benign attitude towards them' (p. 219).

We selected four areas in unprotected landscapes with hardly any forest cover but with a high density of chimpanzees and with reported instances of human-chimpanzee competition for resources, based on national census data (Brncic et al., 2010). Our aims were to identify the key challenges to agricultural productivity for people in these landscapes, assess the mitigation strategies currently used by farmers to protect their crops from wildlife, understand the farmers' perceptions of chimpanzees and their current status in their locality, and evaluate the perceived impact of crop losses caused by chimpanzees relative to other wildlife in each study area.

\section{Study areas}

The study took place in four locations in Sierra Leone: Lawana and Moseilelo in the Moyamba district, and Port Loko South and Port Loko North in the Port Loko district (Fig. 1; Table 1). Active and fallow farms at various stages of growth dominate these four areas. Wild or feral oil palms Elaeis guineensis are the most frequently encountered tree species across these agricultural matrices, together with rough-skin plum trees Parinari excelsa (Plate 1). Oil palms are an important non-cultivated resource that people harvest locally for palm oil, palm wine, nuts and construction materials. However, the sites differ in several ways: Lawana is located between mangroves and swamp areas (Plate 1); Moseilelo harbours a small and highly degraded area of secondary forest, known as the Kasillah Hills; Port Loko North is dominated by grassland and woodland savannah, and also harbours small-scale oil palm plantations; whereas Port Loko South is more swampy and harbours a higher number of small-scale commercial oil palm plantations located primarily near human settlements. Both areas of Port Loko 


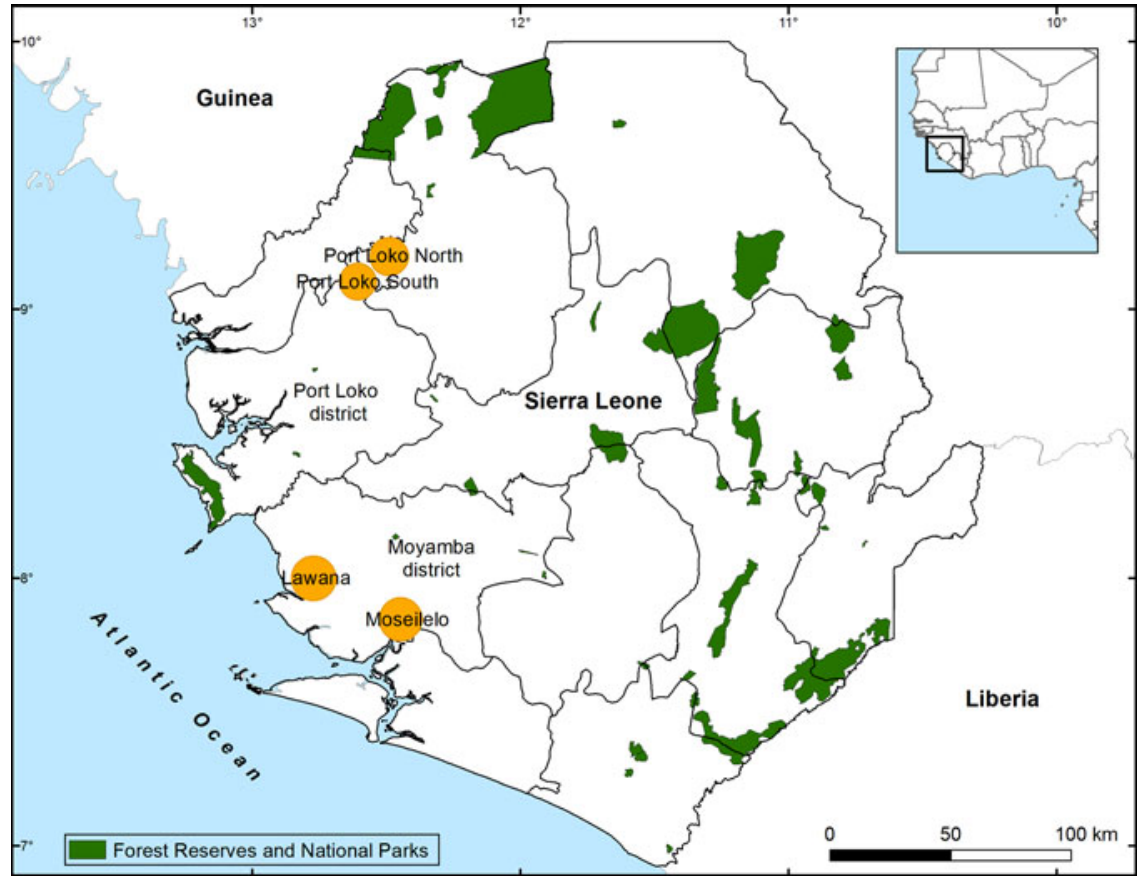

FIG. 1 Location of the four study areas (Port Loko North, Port Loko South, Lawana and Moseilelo) in Sierra Leone. have multiple narrow riverine forests spanning the landscape. Moseilelo and both areas of Port Loko are also delimited by two large rivers, which form a fork and potentially act as a barrier to wildlife dispersal (Fig. 2). Both men and women are involved in farming activities in these areas, cultivating mainly seasonal crops (RMG, pers. obs.). Apart from the Sierra Leone National Chimpanzee Census Project (Brncic et al., 2010) there had been no previous research on chimpanzees in these areas.

\section{Methods}

\section{Semi-structured interviews}

We conducted 257 semi-structured interviews with farmers in 61 villages ( 23 in the Moyamba district and 38 in the Port Loko district) during December 2012-January 2014 (Table 1). The mean time taken to complete an interview was $27 \pm$ SD 9 minutes (range 9-77). Among the participants, $80.2 \%$ were males and $19.8 \%$ were females. Given the significant sex-bias (Table 1), we refrained from conducting any analysis exploring gender differences. The mean age of the participants was $43 \pm$ SD 14.08 years (range 19-90). The majority of the participants (93.9\%) were farmers, and $3.8 \%$ of them combined farming with other occupations, including trading $(n=4)$, teaching $(n=3)$, fishing $(n=2)$ and pot making $(n=1)$. The dominant ethnicity varied across sites (Table 2); the majority (95.7\%) described themselves as Muslim. Nearly two-thirds (63.4\%) of the participants reported not having received any formal education (Table 2 ).
The study was approved by the Research Ethics Committee of the School of Anthropology and Conservation at the University of Kent, UK, and adhered to the code of best practices for field primatology issued by the International Society of Primatology. The interviews were anonymous and voluntary. We conducted one interview per household. We first asked permission from the village chief; interviewers then dispersed in various directions from the centre to the periphery of each village, selecting households at random. The interviews were conducted in the local language by four Sierra Leoneans from the Tacugama Chimpanzee Sanctuary field team, who had been trained by RMG. To cover a wide geographical area in each locality we conducted interviews in every second village as we passed through. The interviews were designed to determine (1) the socio-cultural profile of participants; (2) the types of crops cultivated locally and the causes of crop losses (this last question was inadvertently omitted in the questionnaire in the Moseilelo area, which was therefore not included in this analysis); (3) the local occurrence of wildlife, identified by means of a field guide, and the type of crops the identified wildlife were reported to consume; (4) which three species were considered to cause the most crop damage; (5) the measures of protection employed locally to deter wildlife from feeding on crops; and (6) people's perceptions of chimpanzees (i.e. do they perceive them to be dangerous and why, and how do they react when they encounter chimpanzees in the fields?) and the farmers' perceptions of the changes in chimpanzee numbers since before the civil war, which occurred during 1991-2002.

The identification guide compiled for use in the interviews contained 43 drawings of West African mammal 
TABLE 1 Details of the four study areas in the Moyamba and Port Loko districts of Sierra Leone (Fig. 1).

\begin{tabular}{|c|c|c|c|c|c|c|c|}
\hline Study area & $\begin{array}{l}\text { Altitude } \\
(\mathrm{m})\end{array}$ & Study period & $\begin{array}{l}\text { No. of } \\
\text { villages } \\
\text { visited }\end{array}$ & $\begin{array}{l}\text { No. of } \\
\text { interviews }\end{array}$ & $\begin{array}{l}\text { Male : female } \\
\text { ratio of } \\
\text { participants }\end{array}$ & Land characteristics & Types of cultivars \\
\hline \multicolumn{8}{|l|}{$\begin{array}{l}\text { Moyamba district } \\
\left(46 \text { people per } \mathrm{km}^{2}\right)^{\star}\end{array}$} \\
\hline Moseilelo $\left(35 \mathrm{~km}^{2}\right)$ & $20-182$ & Feb.-Mar. 2013 & 10 & 38 & $36: 2$ & $\begin{array}{l}\text { The Kasillah Hills lie in the centre of } \\
\text { the study area, characterized by a } \\
\text { highly degraded secondary forest. } \\
\text { The surrounding landscape is com- } \\
\text { posed of swamps, \& cultivated \& } \\
\text { fallow farm land, with wild oil palms } \\
\text { throughout. }\end{array}$ & $\begin{array}{l}\text { Swamps with rice, upland farms } \\
\text { with rice \& cassava intercropped } \\
\text { with sesame, sorghum, maize \& } \\
\text { potato. }\end{array}$ \\
\hline \multicolumn{8}{|l|}{$\begin{array}{l}\text { Port Loko district } \\
\left(104 \text { people per } \mathrm{km}^{2}\right)^{\star}\end{array}$} \\
\hline Port Loko North $\left(86 \mathrm{~km}^{2}\right)$ & $40-80$ & Dec. 2013-Jan. 2014 & 14 & 71 & $53: 18$ & $\begin{array}{l}\text { Landscape dominated by grassland } \\
\& \text { woodland savannah. Cultivated \& } \\
\text { fallow farms. Wild oil palms } \\
\text { throughout. }\end{array}$ & $\begin{array}{l}\text { Upland farms are cultivated with } \\
\text { cassava \& upland rice intercropped } \\
\text { with maize, sesame \& sorghum. } \\
\text { Peanut farms. Small-scale commer- } \\
\text { cial oil palm plantations. Cattle } \\
\text { farming. }\end{array}$ \\
\hline Port Loko South $\left(108 \mathrm{~km}^{2}\right)$ & $30-75$ & Oct.-Nov. 2013 & 24 & 97 & $75: 22$ & $\begin{array}{l}\text { Swamps, cultivated \& fallow farm } \\
\text { land. Riverine forests. Small-scale oil } \\
\text { palm farms. Wild oil palms } \\
\text { throughout. }\end{array}$ & $\begin{array}{l}\text { Swamps with rice, upland farms } \\
\text { with cassava \& rice intercropped } \\
\text { with maize, sesame \& sorghum in } \\
\text { the upland farms. Peanut farms. } \\
\text { Abundant small-scale commercial } \\
\text { oil palm plantations. }\end{array}$ \\
\hline
\end{tabular}

${ }^{*}$ Statistics Sierra Leone (2016) 


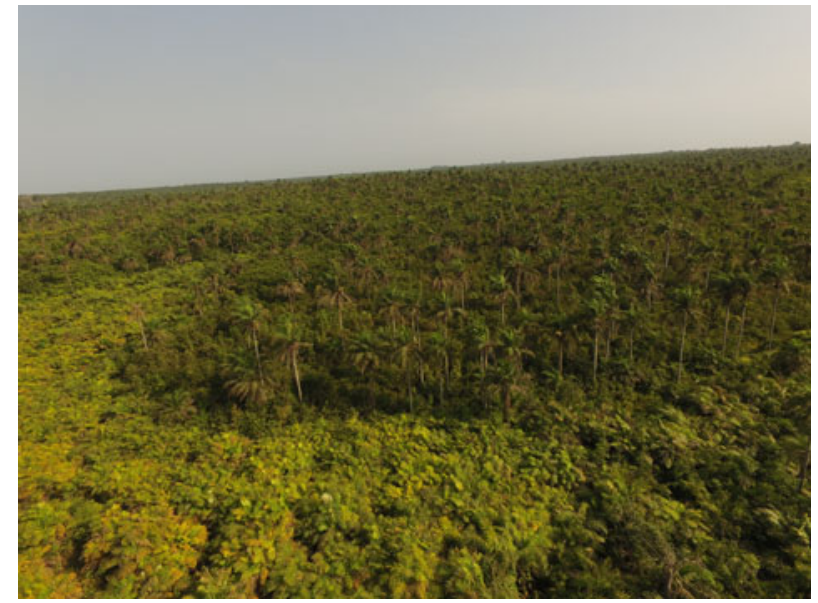

Plate 1 The characteristic landscape of the Lawana study area (Fig. 1), comprising agricultural land and swamp areas, with wild oil palms Elaeis guineensis abundant throughout. (Photograph by Josep M. Fortuny).

species (Kingdon, 2001; Oates, 2010). The selection of images was tested on a pilot group of 10 Sierra Leoneans before the start of the study to ensure that people could recognize the species portrayed. When participants identified a species they believed to exist in their area, we asked whether the species in question consumed crops, and which type. We then tallied the number of times each crop was reported as being consumed by each species to calculate percentages of reported crop foraging.

\section{Data analysis}

We produced maps using ArcGIS 10.3 (ESRI, Redlands, USA) and analysed data using SPSS v. 23 (IBM, Armonk, USA). Chi-square tests were used to explore differences between sites in the types of crops grown, crop protection measures used, the perceived changes in the number of chimpanzees since before the civil war, people's perceptions of chimpanzees as being dangerous, and reports of how chimpanzees react when encountered in cultivated fields. For $\chi^{2}$ tests with more than a $2 \times 2$ contingency design, the $z$-scores based on the adjusted standardized residuals were used to assess the cell contribution to significant $\chi^{2}$ results with values $\geq 1.96$ yielding statistical significance at $\mathrm{P}<0.05$.

\section{Results}

\section{Crops cultivated and reported causes of crop losses}

Farmers reported cultivating a variety of seasonal crops using intercropping practices. Unlike swamp fields, which were planted exclusively with rice, upland farms were cultivated with a mixture of crops simultaneously (Table 3 ).
Seasonal crops were the most reported cultivars grown by farmers in all areas (82.7 \pm SD 6.7\%). There was a significant difference in the types of crops reported across sites $\left(\chi^{2}\right.$ test: $\chi(6)=41.163, \mathrm{P}<0.001)$, with the $z$-scores indicating a significantly higher frequency of domestic fruit crops and cash tree crops at Port Loko South relative to the other sites, and significantly fewer than expected cash tree crops in both Lawana and Moseilelo. However, there was no significant difference in the reporting of seasonal crops being cultivated across the four sites (Table 3 ). In all cases the harvests were used for subsistence, although 66.1\% (170 of 257) of participants reported selling any surplus, with farmers in Lawana reporting selling the least $(25.5 \%)$ compared to the other three sites (Moseilelo: 60.5\%; Port Loko North: 78.9\%; Port Loko South: 80.4\%).

In the Lawana area the reported challenges to agricultural productivity were crop foraging by wild mammals (76.5\%), poor soil quality (51\%), and plagues of grasshoppers Zonocerus variegatus (9.8\%), whereas in the Port Loko district farmers reported crop foraging by wild mammals (Port Loko North: 98.6\%; Port Loko South: 96.9\%), grasshoppers (Port Loko North: 78.9\%; Port Loko South: 83.5\%), birds feeding on crops (Port Loko North: 7\%; Port Loko South: 7.2\%), poor soil quality (Port Loko North: $4.2 \%$; Port Loko South: $14.4 \%$ ) and lack of fertilizer (Port Loko North: $1.4 \%$; Port Loko South: 4.1\%). Foraging by domestic animals was mentioned as a problem only once, in Port Loko South.

Rice and cassava, the two most reported cultivated crops (Table 3), were also the most reported as being damaged by wild mammals. In contrast, sesame and sorghum were rarely reported as being consumed by wild mammals (Table 3 ). Other cultivars, such as chilli pepper and okra, attracted fewer species, with duikers Cephalophus and Philantomba spp. and bushbucks Tragelaphus spp. mentioned most often as feeding on the leaves. Domestic fruit crops comprised only $9.6 \pm$ SD $2.9 \%$ of the cultivars reported to be cultivated across all four areas, and primates were considered to be the main consumers (75.6 \pm SD 12.7\%), with $32.8 \pm$ SD $16.6 \%$ of consumption attributed to chimpanzees. Cash tree crops accounted for only $7.7 \pm$ SD $3.9 \%$ of the total cultivars reported. Small, commercial oil palm plantations were common in both areas of Port Loko district but not in Lawana or Moseilelo. However, farmers in all four areas regarded losses of oil palm to wildlife as a serious problem, and oil palm was reported as the third most frequently raided crop in all areas except Moseilelo, where it was ranked fifth (Table 4). Chimpanzees were the most frequently mentioned culprits, although up to 30 species of fauna were reported to exploit oil palms.

Chimpanzees reportedly targeted 21 types of crops, but with a lower frequency compared to cane rats, which were reported to target up to 20 crops (Table 5). Cane rats were reported to feed mainly on rice and cassava, and to a lesser extent on maize and peanuts, damaging all stages of the 

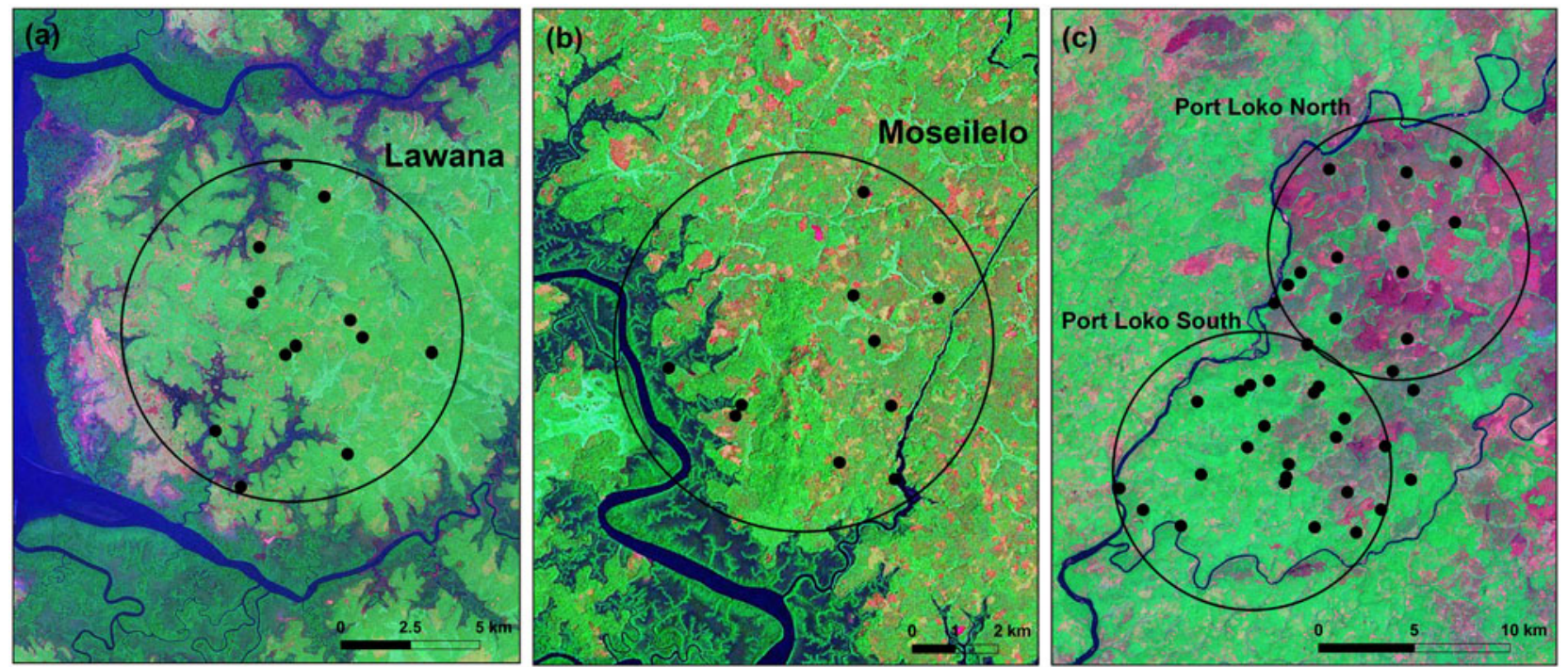

FIG. 2 The locations of the villages where interviews were conducted in (a) Lawana, (b) Moseilelo and (c) Port Loko North and South. The locations in Sierra Leone are shown in Fig. 1.

TABLE 2 Socio-cultural profile of farmers interviewed in the four study areas (Fig. 1).

\begin{tabular}{|c|c|c|c|c|c|}
\hline & \multicolumn{4}{|c|}{ No. of individuals (\%) } & \multirow[b]{2}{*}{ Total } \\
\hline & $\begin{array}{l}\text { Lawana } \\
\text { (51 interviews) }\end{array}$ & $\begin{array}{l}\text { Moseilelo } \\
\text { (38 interviews) }\end{array}$ & $\begin{array}{l}\text { Port Loko North } \\
\text { (71 interviews) }\end{array}$ & $\begin{array}{l}\text { Port Loko } \\
\text { South (97 interviews) }\end{array}$ & \\
\hline \multicolumn{6}{|l|}{ Education } \\
\hline No formal education & $36(70.6)$ & $27(71.1)$ & $53(74.6)$ & $47(48.9)$ & $1639(63.4)$ \\
\hline Arabic school & $7(13.7)$ & $6(15.8)$ & $11(15.5)$ & $31(32)$ & $55(21.4)$ \\
\hline English school & $8(15.7)$ & $5(13.2)$ & $7(9.9)$ & $19(19.6)$ & $39(15.2)$ \\
\hline \multicolumn{6}{|l|}{ Religion } \\
\hline Christian & & $2(5.3)$ & $7(9.9)$ & & $9(3.5)$ \\
\hline Muslim & $51(100)$ & $34(89.5)$ & $56(78.9)$ & 96 (99) & $237(92.2)$ \\
\hline No response & & $2(5.3)$ & $8(11.3)$ & $1(1)$ & $11(4.3)$ \\
\hline \multicolumn{6}{|l|}{ Ethnic group } \\
\hline Krio & & & $2(2.8)$ & & $11(4.3)$ \\
\hline Limba & & & $42(59.2)$ & $3(3.1)$ & 45 (17.5) \\
\hline Mende & $1(2)$ & $33(86.8)$ & $1(1.4)$ & & $35(13.6)$ \\
\hline Shabro & $42(82.4)$ & $3(7.9)$ & & & $45(17.5)$ \\
\hline Temne & $8(15.7)$ & $2(5.3)$ & $25(35.2)$ & $94(96.9)$ & $129(50.2)$ \\
\hline No response & & & $1(1.4)$ & & $1(1.4)$ \\
\hline
\end{tabular}

plants' growth. The giant-pouched rat Cricetomys emini, the green monkey Chlorocebus aethiops sabaeus and the firefooted rope squirrel Funisciurus pyrropus consumed a similar number of crops (20-21), with a similar frequency. Green monkeys and sooty mangabeys Cercocebus atys were reported to target the same number of crops; however, sooty mangabeys were reported more frequently in Lawana and Moseilelo, and green monkeys in Port Loko. As a group, monkeys were reported to consume similar cultivars across all four study areas, primarily maize, rice, cassava and peanuts.

The mean number of animal species identified per interview was $11 \pm$ SD 4.25 (range 2-26). Of the species considered to be crop foragers, cane rats, chimpanzees, giant pouched rats and fire-footed rope squirrels were the most mentioned (Fig. 3), and in all four areas farmers perceived that cane rats caused the most damage to crops (Fig. 4). Overall, chimpanzees ranked as the fourth most destructive mammal; however, there was some variation across sites. In Lawana chimpanzees were ranked second, and in Moseilelo fourth, whereas they were ranked seventh in Port Loko North and fifth in Port Loko South. One regular complaint of the farmers in the two Port Loko sites was the destruction of crops by grasshoppers, which was not mentioned at either of the sites in the Moyamba district (Fig. 4). 
TABLE 3 No. of reports of crops cultivated in each of the four study areas (Fig. 1).

\begin{tabular}{|c|c|c|c|c|}
\hline & \multicolumn{4}{|c|}{ No. of reports (\%) } \\
\hline & Lawana & Moseilelo & Port Loko North & Port Loko South \\
\hline Domestic fruit crops & $13(5.7)$ & $15(7.6)$ & $47(8.3)$ & $90(12.5)$ \\
\hline Banana Musa spp. & $4(7.8)^{\star}$ & $11(28.9)^{*}$ & $14(19.7)^{\star}$ & $42(43.3)^{\star}$ \\
\hline Pineapple Ananas comosus & $6(11.8)^{*}$ & $4(10.5)^{*}$ & $5(7)^{\star}$ & $21(21.6)^{*}$ \\
\hline Orange Citrus sinensis & $2(3.9)^{*}$ & $*$ & $8(11.3)^{*}$ & $11(11.3)^{*}$ \\
\hline Papaya Carica papaya & $1(2)^{\star}$ & * & $10(14.1)^{*}$ & $7(7.2)^{*}$ \\
\hline Mango Mangifera spp. & & & $7(9.9)^{\star}$ & $8(8.2)^{\star}$ \\
\hline Others & & & $3(4.2)$ & $1(1)$ \\
\hline Cash tree crops & $5(1.6)$ & $7(3.6)$ & $40(7.6)$ & $76(10.9)$ \\
\hline Oil palm Elaeis guineensis & $3(5.9)^{*}$ & $2(5.3)^{*}$ & $34(47.9)^{*}$ & $66(68)^{*}$ \\
\hline Kola nut Cola sp. & $1(2)^{*}$ & & $3(4.2)$ & $7(7.2)$ \\
\hline Cacao Theobroma cacao & $1(2)$ & $4(10.5)$ & $1(1.4)^{\star}$ & $2(2.1)$ \\
\hline Others & & $1(2.6)$ & $2(2.8)$ & $1(1)$ \\
\hline Seasonal crops & $212(92.2)$ & $175(88.8)$ & $479(84.5)$ & $556(76.9)$ \\
\hline Rice Oryza spp. & $50(98)^{\star}$ & $37(97.4)^{*}$ & $71(100)^{\star}$ & $92(94.8)^{*}$ \\
\hline Cassava Manihot esculenta & $45(88.2)^{*}$ & $35(92.1)^{*}$ & $66(93)^{*}$ & $81(83.5)^{*}$ \\
\hline Sesame Sesamum sp. & $32(62.7)^{*}$ & $30(78.9)^{*}$ & $41(57.7)^{*}$ & $47(48.5)^{*}$ \\
\hline Chilli pepper Capsicum spp. & $4(7.8)$ & $2(5.3)^{\star}$ & $54(76.1)$ & $65(67)$ \\
\hline Peanuts Arachis hypogaea & $9(17.6)$ & $2(5.3)^{*}$ & $48(67.6)^{\star}$ & $65(67)^{\star}$ \\
\hline Maize Zea mays & $9(17.6)^{*}$ & $16(42.1)^{*}$ & $35(49.3)^{*}$ & $48(49.5)^{*}$ \\
\hline Beans Phaseolus spp. & $16(31.4)^{*}$ & $4(10.5)^{*}$ & $40(56.3)^{\star}$ & $42(43.3)^{*}$ \\
\hline Potato Solanum tuberosum & $5(9.8)^{\star}$ & $14(36.8)$ & $34(47.9)$ & $38(39.2)^{\star}$ \\
\hline Sorghum Sorghum bicolor & $31(60.8)$ & $25(65.8)$ & $7(9.9)$ & $8(8.2)$ \\
\hline Okra Abelmoschus esculentus & $7(13.7)$ & & $26(36.6)$ & $30(30.9)^{*}$ \\
\hline Yam Dioscorea spp. & $1(2)$ & $9(23.7)^{*}$ & $15(21.1)$ & $14(12.4)$ \\
\hline Pumpkin Cucurbita spp. & $2(3.9)^{\star}$ & * & $14(19.7)$ & $12(12.4)^{*}$ \\
\hline Others & $1(2)$ & $1(2.6)$ & $28(39.4)$ & $14(14.4)$ \\
\hline
\end{tabular}

${ }^{*}$ Crops reported to be consumed by chimpanzees Pan troglodytes verus (this does not necessarily coincide with the crops people reported cultivating, as they sometimes omitted to mention domestic fruit such as mangoes, oranges and papaya).

\section{Crop protection measures}

All but eight of the participants (249 of 257) reported using one or more mitigation measures against crop foraging by wild animals. More mitigation measures were reported at the Port Loko sites than at Lawana and Moseilelo (Table 6). Fencing (223 of 249) and traps (208 of 249) were the most common deterrents used to prevent wildlife from entering cultivated farms. Usually fences were hand-made with palm leaves and/or sticks interspersed with snares. Hunting with dogs was more common in the Port Loko district, with $49.4 \%$ ( 81 of 164) reporting use compared to only $7 \%$ (6 of 85 ) in the Moyamba district. However, if each measure is categorized as (potentially) lethal or non-lethal (Table 6), there were no differences among sites $\left(\chi^{2}\right.$ test: $\left.\chi(3)=2.243, P=0.523\right)$.

\section{Farmers' perceptions of chimpanzees}

Nearly all of the participants (253 of 257; 98\%) stated that chimpanzees used to enter their farms before the civil war (19912002) and $63 \%$ (160 of 253) perceived that there were fewer chimpanzees now than before the war, mostly as a result of deforestation and hunting (118 of 160). Only 36.4\% (92 of 253) thought there were more chimpanzees now and the only reason stated in $45 \%$ ( 41 of 92) of the responses was that they were not hunted. No other reasons were given. Whether farmers perceived there were more or fewer chimpanzees since before the civil war differed significantly among sites $\left(\chi^{2}\right.$ test: $\chi(3)=82.255, \mathrm{P}<0.001)$. Based on the $z$-scores, in Lawana significantly more people than expected thought there were more chimpanzees than before the civil war, whereas there was no significant difference for Moseilelo. However at both Port Loko sites people thought there were significantly fewer chimpanzees than before the civil war.

Eighty seven percent (224 of 257) of respondents considered chimpanzees to be dangerous, the most common reason being that they destroy crops $(48.7 \%, 109$ of 224). They were also considered to be dangerous because they are destructive and frightening $(5.8 \%, 13$ of 224), frightening $(28.1 \%, 63$ of 224$)$ or aggressive $(2.7 \%, 6$ of 224$)$. There was no significant difference among sites regarding whether people perceived chimpanzees to be dangerous or not $\left(\chi^{2}\right.$ test: $\left.\chi(3)=2.601, \mathrm{P}=0.457\right)$.

Ninety four percent (241 of 257) of participants reported currently encountering chimpanzees in their fields, with little variation across study areas (Lawana: 96\%; Moseilelo: 
TABLE 4 No. of reports of wildlife foraging on various cultivars (N), and frequency of reported foraging (FF) and crop cultivation (FC) as percentages in each study area.

\begin{tabular}{|c|c|c|c|c|c|c|c|c|c|c|c|c|}
\hline \multirow[t]{2}{*}{ Crop } & \multicolumn{3}{|c|}{ Lawana } & \multicolumn{3}{|c|}{ Moseilelo } & \multicolumn{3}{|c|}{ Port Loko North } & \multicolumn{3}{|c|}{ Port Loko South } \\
\hline & $\mathrm{N}$ & FF \% & FC \% & $\mathrm{N}$ & FF \% & FC \% & $\mathrm{N}$ & FF \% & FC \% & $\mathrm{N}$ & FF \% & FC $\%$ \\
\hline Aubergine Solanum melongena & 3 & 0.4 & 2 & 0 & 0 & 2.6 & 0 & 0 & 11.3 & 1 & 0.04 & 3.1 \\
\hline Banana & 16 & 6.2 & 7.8 & 14 & 3.8 & 28.9 & 11 & 1.9 & 19.7 & 15 & 3.1 & 43.3 \\
\hline Bean & 12 & 3.1 & 31.4 & 15 & 1.9 & 10.5 & 8 & 2.1 & 56.3 & 10 & 1.5 & 43.3 \\
\hline Cacao & 0 & 0 & 2 & 2 & 0.1 & 10.5 & 4 & 0.3 & 1.4 & 0 & 0 & 2.1 \\
\hline Cassava & 28 & 29.6 & 88.2 & 25 & 28.8 & 92.1 & 26 & 19.3 & 93 & 27 & 17.5 & 83.5 \\
\hline Chilli pepper & 3 & 2.0 & 7.8 & 7 & 2.1 & 5.3 & 13 & 4.7 & 76.1 & 15 & 3.8 & 67.0 \\
\hline Coffee Coffea sp. & 0 & 0 & 0 & 0 & 0 & 2.6 & 0 & 0 & 2.8 & 1 & 0.04 & 0 \\
\hline Cucumber Cucumis sativus & 2 & 0.2 & 0 & 10 & 1.1 & 0 & 4 & 0.5 & 23.9 & 1 & 0.04 & 7.2 \\
\hline Kola nut & 8 & 2.8 & 2 & 3 & 0.4 & 0 & 9 & 1.3 & 4.2 & 6 & 0.5 & 7.2 \\
\hline Maize & 10 & 3.1 & 17.6 & 17 & 12.9 & 42.1 & 15 & 8.4 & 49.3 & 14 & 6.2 & 49.5 \\
\hline Mango & 2 & 0.2 & 0 & 5 & 0.4 & 0 & 9 & 2.0 & 9.9 & 12 & 2.1 & 8.2 \\
\hline Millet Pennisetum sp. & 0 & 0 & 0 & 0 & 0 & 0 & 3 & 0.3 & 4.2 & 3 & 0.2 & 4.1 \\
\hline Oil palm & 14 & 10.5 & 5.9 & 15 & 5.9 & 5.3 & 21 & 11.6 & 47.9 & 27 & 14 & 68 \\
\hline Okra & 5 & 3.8 & 13.7 & 5 & 2.6 & 0 & 7 & 1.5 & 36.6 & 7 & 1.6 & 30.9 \\
\hline Orange & 9 & 4.6 & 3.9 & 4 & 0.3 & 0 & 9 & 2.7 & 11.3 & 11 & 3.5 & 11.3 \\
\hline Papaya & 5 & 1.1 & 2 & 5 & 0.6 & 0 & 8 & 1.3 & 14.1 & 5 & 1.1 & 7.2 \\
\hline Peanut & 14 & 10.3 & 17.6 & 18 & 9.6 & 5.3 & 19 & 11.6 & 67.6 & 22 & 13.9 & 67 \\
\hline Pineapple & 6 & 1.3 & 11.8 & 3 & 0.8 & 10.5 & 1 & 0.3 & 7 & 8 & 0.9 & 21.6 \\
\hline Plum Spondias dulcis & 0 & 0 & 0 & 0 & 0 & 0 & 7 & 0.8 & 4.2 & 9 & 0.6 & 0 \\
\hline Potato & 10 & 1.9 & 9.8 & 13 & 2.4 & 36.8 & 17 & 6.7 & 47.9 & 18 & 5.2 & 39.2 \\
\hline Pumpkin & 7 & 1.2 & 3.9 & 9 & 1.3 & & 7 & 2 & 19.7 & 19 & 2.6 & 12.4 \\
\hline Rice & 22 & 14 & 98 & 25 & 18.4 & 97.4 & 29 & 17.3 & 100 & 27 & 19.3 & 94.8 \\
\hline Sesame & 5 & 0.6 & 62.7 & 8 & 1.1 & 78.9 & 8 & 1.4 & 57.7 & 7 & 1 & 48.5 \\
\hline Sorghum & 8 & 3.3 & 60.8 & 8 & 1.4 & 65.8 & 1 & 9.9 & 0.1 & 2 & 0.1 & 8.2 \\
\hline Yam & 0 & 0 & 2 & 16 & 4.1 & 23.7 & 9 & 2.1 & 21.1 & 7 & 1.2 & 14.4 \\
\hline
\end{tabular}

94.7\%; Port Loko North: 90.1\%; Port Loko South: 96.9\%). When asked how the chimpanzees respond when they are encountered, $81.7 \%$ (197 of 241) reported that chimpanzees run away, and $12.9 \%$ (31 of 241) reported that they threaten people. There was a significant difference in responses among sites $\left(\chi^{2}: \chi(3)=9.702, \mathrm{P}=0.021\right)$. Although there was no significant difference in reports of chimpanzees running away, fewer people reported chimpanzees threatening people in Lawana, and significantly more in Port Loko South.

\section{Discussion}

We found that cane rats were perceived to be the most problematic mammal for farmers in the study areas. Other studies have reported the cane rat to be a problem species (Naughton-Treves \& Treves, 2005), and it was found to cause the most severe damage to crops around a forest reserve in Cameroon (Arlet \& Molleman, 2007). Cane rats are nocturnal, dependent on water, have high reproductive rates and thrive in areas with abundant grasses (Hoffmann, 2008); the agricultural habitat present at our study sites is well suited to their needs.

No respondents ranked chimpanzees as the most destructive mammal species, and other species, such as the cane rat, the red river hog Potamochoerus porcus, monkeys and grasshoppers, were perceived as causing most damage. Nevertheless, there was variation across sites in the ranking of chimpanzees, possibly linked to variation in the occurrence and abundance of other destructive wildlife species and people's perceptions across sites. However, our results also suggest that farmers' perceptions vary depending on the crops grown and their dependence on agriculture for subsistence. Chimpanzees were ranked higher in Lawana and Moseilelo, where farmers mentioned growing more seasonal crops and fewer cash crops, and reported selling less surplus, indicating a higher dependency on seasonal cultivation for subsistence. The degree to which farmers viewed chimpanzees as a threat to their agricultural yield may also be related to the extent of overlap between the chimpanzees' home range and farmlands in the landscape, the contribution of various crop species to chimpanzees' diet locally (McLennan \& Hill, 2012), whether farmers had direct experience of chimpanzee crop foraging (although there was no reported variation across sites in this study), and their level of tolerance of chimpanzee offtake (although chimpanzees were reportedly less likely to threaten people at Lawana, which indicates that perhaps farmers were more tolerant of chimpanzee crop foraging at this site; Webber \& Hill, 2014). These alternative explanations warrant further investigation to reveal patterns of similarity or difference across sites. 
TABLE 5 Number of different crops reported by farmers as being eaten by wildlife, and the frequency of reporting, for the 13 most reported species in the four study areas (Fig. 1).

\begin{tabular}{|c|c|c|c|c|c|c|c|c|c|c|}
\hline \multirow[b]{2}{*}{ Species } & \multicolumn{2}{|c|}{ All areas } & \multicolumn{2}{|c|}{ Lawana } & \multicolumn{2}{|c|}{ Moseilelo } & \multicolumn{2}{|c|}{ Port Loko North } & \multicolumn{2}{|c|}{ Port Loko South } \\
\hline & $\begin{array}{l}\text { No. of } \\
\text { crops }\end{array}$ & $\begin{array}{l}\text { Frequency } \\
(\%)\end{array}$ & $\begin{array}{l}\text { No. of } \\
\text { crops }\end{array}$ & $\begin{array}{l}\text { Frequency } \\
(\%)\end{array}$ & $\begin{array}{l}\text { No. of } \\
\text { crops }\end{array}$ & $\begin{array}{l}\text { Frequency } \\
(\%)\end{array}$ & $\begin{array}{l}\text { No. of } \\
\text { crops }\end{array}$ & $\begin{array}{l}\text { Frequency } \\
(\%)\end{array}$ & $\begin{array}{l}\text { No. of } \\
\text { crops }\end{array}$ & $\begin{array}{l}\text { Frequency } \\
(\%)\end{array}$ \\
\hline Cane rat Thryonomys swinderianus & 20 & 14 & 9 & 11.2 & 12 & 10.7 & 13 & 15 & 19 & 15.6 \\
\hline Chimpanzee Pan troglodytes verus & 21 & 11.2 & 13 & 13 & 15 & 9.3 & 15 & 9.6 & 17 & 12.5 \\
\hline Giant pouched rat Cricetomys emini & 20 & 9.4 & 6 & 4.6 & 10 & 6.6 & 13 & 10.2 & 17 & 11.6 \\
\hline $\begin{array}{l}\text { Green monkey Chlorocebus aethiops } \\
\text { sabaeus }\end{array}$ & 21 & 8.8 & 9 & 2.1 & 13 & 5.6 & 16 & 9.9 & 20 & 11.7 \\
\hline $\begin{array}{l}\text { Fire-footed rope squirrel Funisciurus } \\
\text { pyrropus }\end{array}$ & 20 & 7.8 & 7 & 6.9 & 10 & 6 & 17 & 8.9 & 13 & 7.9 \\
\hline Bushbuck Tragelaphus scriptus & 14 & 6.3 & 9 & 9.2 & 8 & 7.4 & 7 & 6.1 & 12 & 5 \\
\hline Crested porcupine Hystrix cristata & 17 & 4.9 & 7 & 4.5 & 11 & 2.9 & 13 & 6.7 & 12 & 4.5 \\
\hline Sooty mangabey Cercocebus atys & 21 & 4.9 & 13 & 6.5 & 10 & 8.4 & 14 & 3.7 & 14 & 3.7 \\
\hline Red river hog Potamochoerus porcus & 11 & 4.7 & 3 & 1.8 & 5 & 4.1 & 6 & 5.3 & 11 & 5.5 \\
\hline $\begin{array}{l}\text { Brush-tailed porcupine Atherurus } \\
\text { africanus }\end{array}$ & 15 & 3.8 & 5 & 2.8 & 11 & 7.1 & 11 & 3.9 & 10 & 2.5 \\
\hline $\begin{array}{l}\text { Giant forest squirrel Protoxerus } \\
\text { stangeri }\end{array}$ & 18 & 3.5 & 8 & 2.9 & 6 & 2 & 15 & 4.3 & 13 & 3.7 \\
\hline $\begin{array}{l}\text { Maxwell's duiker Cephalophus } \\
\text { maxwellii }\end{array}$ & 14 & 3 & 8 & 3.5 & 9 & 5.3 & 8 & 3.1 & 5 & 1.6 \\
\hline $\begin{array}{l}\text { Giant forest hog Hylochoerus } \\
\text { meinertzhageni }\end{array}$ & 12 & 2.7 & 7 & 5.9 & 5 & 2 & 7 & 2.8 & 7 & 1.9 \\
\hline
\end{tabular}




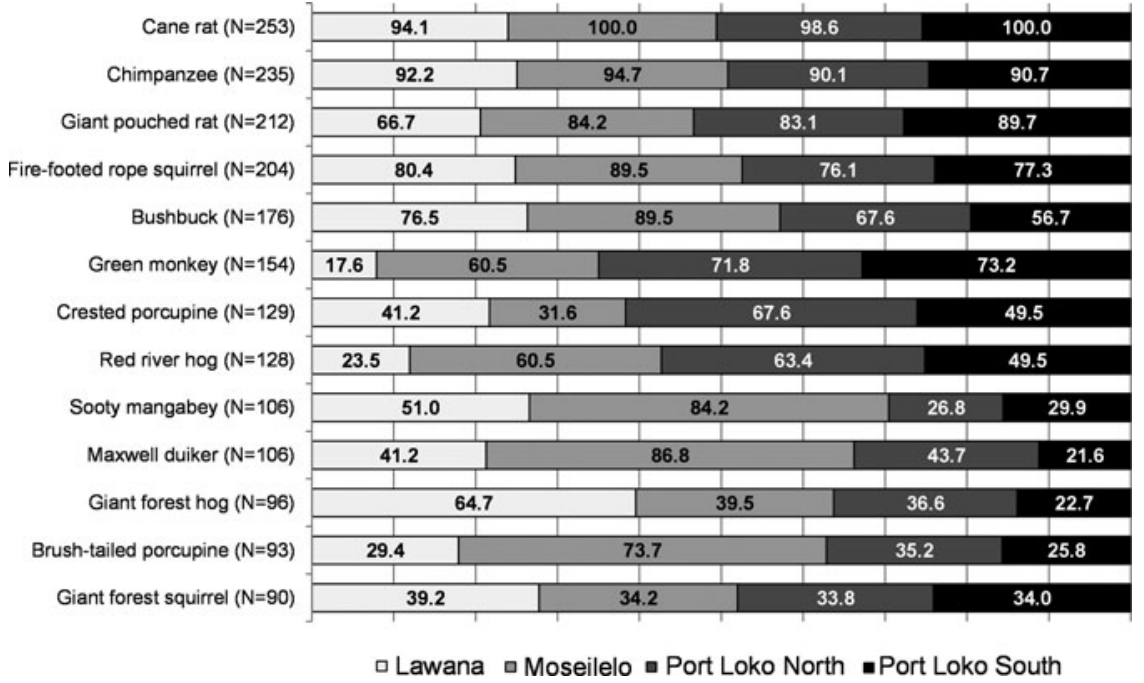

FIG. 3 The total number of respondents across the four study areas $(\mathrm{N})$ and the percentage of respondents in each study area who identified various species as crop raiders.
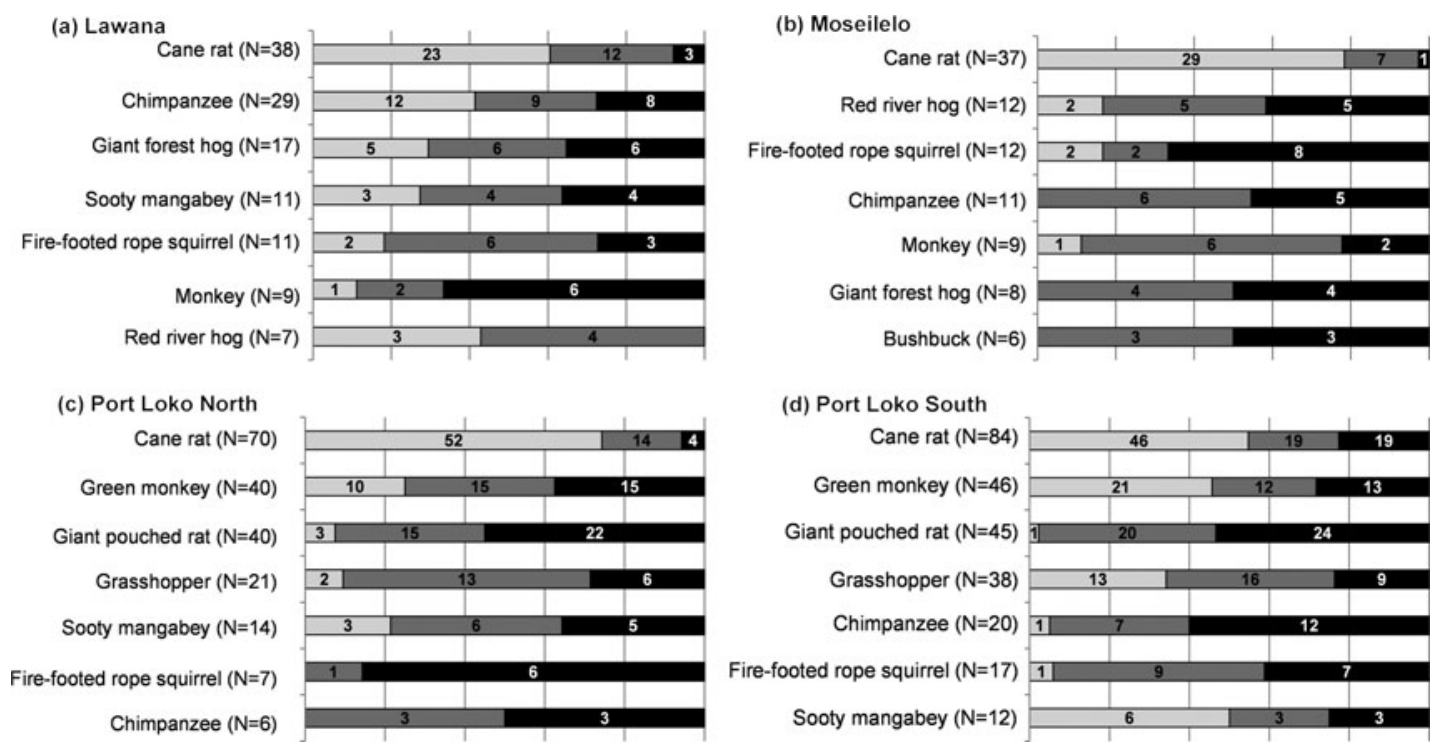

FIG. 4 Ranking of the most destructive species in (a) Lawana, (b) Moseilelo, (c) Port Loko North and (d) Port Loko South (Fig. 1), with the number of times each species was ranked as first, second or third most destructive, from left to right.

We recorded significant evidence of chimpanzees using oil palms across all four study areas. The most visible and common use by chimpanzees was for nesting. Commercial oil palms are predominantly cultivated in the two Port Loko areas (Table 3 ) but during our time in the field we did not record any evidence of chimpanzees using them. Usually these plantations are cultivated near human settlements, potentially reducing their accessibility to chimpanzees. Based on our in situ observations, competition for oil palm mainly concerns wild oil palms, which are widespread and are an important resource to farmers. Chimpanzees at other sites have also demonstrated extensive reliance on oil palms for food and nesting (e.g. Bossou, Guinea: Humle \& Matsuzawa, 2004; Guinea-Bissau: Sousa et al., 2011; Bessa et al., 2015). Further research is needed to assess the extent to which chimpanzees across various landscapes depend on the oil palm for food and nesting.

Hockings \& McLennan (2012) found that cassava was not widely eaten by chimpanzees across their range and that they preferred sugar fruits. In our study, chimpanzees were reported to forage frequently on cassava, probably because of its wider and easier availability compared to other cultivars, such as banana, mango, pineapple or papaya. Domestic fruit crops comprised $<10 \%$ of the crops cultivated in all four areas, although farmers tended to underreport these (Table 3). Chimpanzees may avoid coming close to the villages, preferring to consume cassava from the more distant fields. Despite occasional reports in 
TABLE 6 Percentage of respondents who reported adopting various measures to protect farms in each of the four study areas (Fig. 1).

\begin{tabular}{|c|c|c|c|c|c|}
\hline \multirow[b]{2}{*}{ Protection measure } & \multirow[b]{2}{*}{ Type } & \multicolumn{4}{|c|}{$\%$ reports } \\
\hline & & Lawana & Moseilelo & Port Loko North & Port Loko South \\
\hline Fencing $(n=223)$ & Non-lethal & 92.2 & 71.1 & 97.2 & 82.5 \\
\hline Traps $(n=208)$ & Lethal & 88.2 & 86.8 & 74.6 & 79.4 \\
\hline Hunting with dogs $(n=91)$ & Lethal & 7.8 & 15.8 & 39.4 & 54.6 \\
\hline Scarecrows $(\mathrm{n}=24)$ & Non-lethal & & 2.6 & 12.7 & 14.4 \\
\hline Sling $(n=26)$ & Lethal & 7.8 & 5.3 & 9.9 & 13.4 \\
\hline Nets $(n=17)$ & Non-lethal & & 5.3 & 8.5 & 9.3 \\
\hline Guarding $(\mathrm{n}=7)$ & Non-lethal & & & & 7.2 \\
\hline Poison $(n=9)$ & Lethal & & & 2.8 & 7.2 \\
\hline Stones $(n=7)$ & Lethal & & & & 7.2 \\
\hline Brushing $(\mathrm{n}=5)$ & Non-lethal & & & & 5.2 \\
\hline Hunting with guns $(\mathrm{n}=4)$ & Lethal & 2.0 & & & 3.1 \\
\hline Shouting $(\mathrm{n}=8)$ & Non-lethal & 2.0 & 2.6 & 4.2 & 3.1 \\
\hline
\end{tabular}

Moseilelo and Port Loko South of farmers seeing chimpanzees near their villages, foraging on domestic fruit trees, such events were rarely reported. It is possible that farmers were more likely to report chimpanzee foraging on a valuable staple crop such as cassava than domestic fruits, which are typically grown around individual households and harvested mainly for self-consumption. A similar situation was described in Uganda (McLennan \& Hill, 2012), where farmers tolerated chimpanzees consuming fruits such as guavas but not cash crops such as sugarcane, cocoa or bananas. Farmers in our study areas reported domestic fruits as being targeted especially by chimpanzees and monkeys. Monkeys seem to be more daring in approaching villages to feed on domestic fruit trees than chimpanzees, as we witnessed on several occasions during our field work. In Guinea and Uganda, however, chimpanzees have been reported entering villages to consume domestic fruits (Hockings \& Humle, 2009; McLennan, 2013). This daring behaviour is potentially linked to people's tolerance of and behaviour towards chimpanzees and the extent to which they can meet their dietary requirements with wild food; habituation could also play a role in influencing the prevalence of such a behaviour (Naughton-Treves et al., 1998; Hockings et al., 2009; McLennan, 2013), although it is not a precondition (McLennan \& Hill, 2010). Sesame, which was widely cultivated across all four areas, and sorghum in Lawana and Moseilelo, were rarely reported as being consumed by wild mammals. This suggests that these may be low-conflict crops (Hockings \& McLennan, 2012; Hockings \& Sousa, 2012) or else farmers may be more tolerant of these crops being consumed by wildlife. The intercropping system used in Sierra Leone provides wildlife with a choice of crops to feed on, and further assessment is required to identify differences between real and perceived damage in mixed vs mono-cultivated fields.

In our study areas, chimpanzees share the habitat with people but are not habituated; usually they run away during encounters with farmers. The absence or limited presence of forest cover at these sites potentially explains why wildlife is dependent upon cultivated and/or abandoned crops for their survival. Local farmers cannot recall seeing large tracts of forest in their area, suggesting that these landscapes were cleared many decades ago. The remaining wild fauna, including chimpanzees, appear to have adapted to this anthropogenic environment. We remain unsure why chimpanzees still persist in these degraded areas; future studies should help us identify more precisely the conditions favouring their persistence.

Almost all farmers interviewed reported adopting crop protection measures. The most common included snares, traps and fences. Fences are erected to prevent larger herbivores from entering cultivated fields, and snares and traps target small mammals. The traps are made of sticks and thin rope or wire. The use of mitigation measures was more prevalent at the Port Loko sites, where most farmers reported selling any harvest surplus, potentially indicating a relationship between monetary income and the ability to protect crops, corroborating findings elsewhere in Africa (Hill \& Wallace, 2012) and South-east Asia (Campbell-Smith et al., 2012). Although some mammals, especially chimpanzees, may be able to escape by dislodging the wire from the trap, the wire could remain tight around the trapped limb and cause severe injury (Quiatt et al., 2002). The impact of wire traps on chimpanzees and other wildlife in our study areas has yet to be assessed. Farmers also reported occasionally hiring hunters to get rid of pests feeding on their crops, typically monkeys, as they are more difficult to catch with snares. Encouraging sustainable and more species-specific hunting practices using more specialized devices to capture rodents could not only decrease crop feeding but could also help improve yields and protect chimpanzees and other mammal species, whilst providing a supplementary source of protein to local people. Cane rats are a favoured and nutritious food source (Hoffman \& Cawthorn, 2012). 
Farmers from both study areas in Port Loko reported that plagues of grasshoppers were a significant challenge, destroying entire fields of cassava and potatoes. A biological insecticide called Green Muscle (Becker Underwood, South Africa) is available from the central government but a lack of resources to implement the project is preventing the product from reaching farmers across the country. Finding solutions for the distribution and implementation of this preventive crop protection measure could help farmers obtain better yields, which could promote greater tolerance of farmers towards key species, such as chimpanzees. However, a heightened expectation of preventability of crop loss could also backfire, lowering farmers' tolerance of damage caused by other species (Knight, 2000), and therefore implementation will require careful monitoring of farmers' tolerance levels. Furthermore, human population growth, which translates into a higher demand for resources (Barnes, 2002), forces farmers to shorten fallow periods, which results in impoverished soil and affects future agricultural productivity (Gaiser et al., 2011). Altogether, such agricultural practices are detrimental to human well-being, as people rely on natural resources provided by the forests, and habitat conversion can cause a decrease in the abundance and diversity of wildlife, which people also depend on for protein (Fa \& Brown, 2009). In three of the four study areas farmers stated that chimpanzee numbers had decreased in the previous 2 decades as a result of deforestation and hunting. To protect wild chimpanzees under such habitat conditions there is a need to work closely with the local communities to help them develop more efficient and sustainable farming techniques to improve their yields, maintain soil fertility and minimize habitat loss as a result of slash-and-burn agriculture.

Almost all participants (94\%) claimed to have seen chimpanzees in their fields. Farmers predominantly stated that chimpanzees run away when encountered in the fields, although some stated that chimpanzees can threaten people because they are not afraid, and could cause injury or death. However, only four participants reported incidents of physical aggression towards people (one in Lawana and three in Port Loko South), adults in all cases, in contrast to Bossou, Guinea, where such attacks mainly involved children (Hockings et al., 2010). Each of these participants felt that chimpanzees were dangerous. Differences between sites may be related to differences in encounter rates between people and chimpanzees (McLennan \& Hockings, 2016) and/or people's behaviour towards chimpanzees (Hockings et al., 2010), and chimpanzees' perception of risk within their environment (Humle \& Hill, 2016). Most participants (87\%) considered chimpanzees to be dangerous. However, almost half argued that it was because chimpanzees were destructive of the crops rather than frightening or aggressive. Nearly two thirds (63\%) of participants also perceived that there were fewer chimpanzees now than before the war; however, in Lawana farmers thought there were more chimpanzees now. This could reflect a local increase in chimpanzee numbers, or higher rates of chimpanzee crop foraging and sighting of chimpanzees in this area compared to other sites.

Although we focused on a subset of locations within Sierra Leone, our findings provide us with a better understanding of human-wildlife coexistence in agricultural landscapes and the factors influencing variability in sympatric relations between people, chimpanzees and other wildlife. Our results highlight variations across study areas, probably linked to differences in habitat types and crops cultivated, and historical patterns of habitat loss. We argue that conservation actions need to be context-specific based on an understanding of local people's perceptions, concerns and attitudes, as well as chimpanzee ecology and distribution in these landscapes. Conservation strategies should benefit and support farmers while promoting a positive coexistence between people and chimpanzees, thus favouring their protection and long-term survival. However, we still need to develop and assess with local and national stakeholders which actions can most effectively improve coexistence between people and chimpanzees, and tolerance levels towards crop-foraging.

\section{Acknowledgements}

We are grateful to the Ministry of Agriculture, Forestry and Food Security of the Sierra Leone Government for granting us permission to conduct this research. This work would not have been possible without the collaboration of the people in the study communities who volunteered to partake in our interviews. We also thank the outreach and management teams at the Tacugama Chimpanzee Sanctuary, in particular Yirah Koroma, Joseph Marah, David Momoh and Konkofa Marah for their assistance in the field. We acknowledge Fundació Barcelona Zoo, the Rufford Small Grants Foundation, the Mohamed bin Zayed Species Conservation Fund and the Tacugama Chimpanzee Sanctuary for the financial support provided to conduct this research, and we thank Matthew McLennan and an anonymous reviewer for their helpful comments.

\section{Author contributions}

RMG, BA and TH conceived and designed the research, which was conducted by RMG. RMG and TH analysed the data and wrote the article, and IM and ECD contributed revisions.

\section{References}

Arlet, M.E. \& Molleman, F. (2007) Rodents damage crops more than wildlife in subsistence agriculture on the northern periphery of 
Dja Reserve, Cameroon. International Journal of Pest Management, $53,237-243$.

BARnES, R.F.W. (2002) The bushmeat boom and bust in West and Central Africa. Oryx, 36, 236-242.

Bessa, J., Sousa, C. \& Hockings, K.J. (2015) Feeding ecology of chimpanzees (Pan troglodytes verus) inhabiting a forest-mangrove-savanna-agricultural matrix at Caiquene-Cadique, Cantanhez National Park, Guinea-Bissau. American Journal of Primatology, 77, 651-665.

Brncic, T., Amarasekaran, B. \& McKenna, A. (2010) Sierra Leone National Chimpanzee Census. Final report. Tacugama Chimpanzee Sanctuary, Freetown, Sierra Leone.

Campbell, G., Kuehl, H., N'Goran Kouamé, P. \& Boesch, C. (2008) Alarming decline of West African chimpanzees in Côte d'Ivoire. Current Biology, 18, R903-R904.

Campbell-Smith, G., Sembiring, R. \& Linkie, M. (2012) Evaluating the effectiveness of human-orangutan conflict mitigation strategies in Sumatra. Journal of Applied Ecology, 49, 367-375.

Carlsen, F., Leus, K., Traylor-Holzer, K. \& McKenna, A. (eds) (2012) Western Chimpanzee Population and Habitat Viability Assessment for Sierra Leone: Final Report. IUCN/SSC Conservation Breeding Specialist Group - Europe, Copenhagen, Denmark.

Cibot, M., Bortolamiol, S., Seguya, A. \& Krief, S. (2015) Chimpanzees facing a dangerous situation: a high-traffic asphalted road in the Sebitoli area of Kibale National Park, Uganda. American Journal of Primatology, 77, 890-900.

Costa, S., Casanova, C., Sousa, C. \& Lee, P.C. (2013) The good, the bad and the ugly: perceptions of wildlife in Tombali (Guinea-Bissau, West Africa). Journal of Primatology, 2, 110.

$F_{A}$, J.E. \& BRown, D. (2009) Impacts of hunting on mammals in African tropical moist forests: a review and synthesis. Mammal Review, 39, 231-264.

Faust, L.J., Cress, D., Farmer, K.H., Ross, S.R. \& Beck, B.B. (2011) Predicting capacity demand on sanctuaries for African chimpanzees (Pan troglodytes). International Journal of Primatology, 32, 849-864.

Gaiser, T., Judex, M., Igué, A.M., Paeth, H. \& Hiepe, C. (2011) Future productivity of fallow systems in Sub-Saharan Africa: is the effect of demographic pressure and fallow reduction more significant than climate change? Agricultural and Forest Meteorology, 151, 1120-1130.

Halloran, A.R., Cloutier, C.T. \& Sesay, P.B. (2013) A previously undiscovered group of chimpanzees (Pan troglodytes verus) is observed living in the Tonkolili district of Sierra Leone. American Journal of Primatology, 75, 519-523.

Hill, C.M. \& Wallace, G.E. (2012) Crop protection and conflict mitigation: reducing the costs of living alongside non-human primates. Biodiversity and Conservation, 21, 2569-2587.

Hockings, K.J. (2011) Behavioral flexibility and division of roles in chimpanzee road-crossing. In The Chimpanzees of Bossou and Nimba (eds T. Matsuzawa, T. Humle \& Y. Sugiyama), pp. 221-229. Springer, London, UK.

Hockings, K.J., Anderson, J.R. \& Matsuzawa, T. (2009) Use of wild and cultivated foods by chimpanzees at Bossou, Republic of Guinea: feeding dynamics in a human-influenced environment. American Journal of Primatology, 71, 636-646.

Hockings, K. \& Humle, T. (2009) Best Practice Guidelines for the Prevention and Mitigation of Conflict Between Humans and Great Apes. IUCN/SSC Primate Specialist Group, Gland, Switzerland.

Hockings, K.J. \& McLennan, M.R. (2012) From forest to farm: systematic review of cultivar feeding by chimpanzees. Management implications for wildlife in anthropogenic landscapes. PLOS ONE, 7 (4), e33391.
Hockings, K.J., McLennan, M.R., Carvalho, S., Ancrenaz, M., Bobe, R., Byrne, R.W. et al. (2015) Apes in the Anthropocene: flexibility and survival. Trends in Ecology \& Evolution, 30, 215-222. Hockings, K.J. \& Sousa, C. (2012) Differential utilization of cashew -a low-conflict crop-by sympatric humans and chimpanzees. Oryx, 46, 375-381.

Hockings, K.J., Yamakoshi, G., Kabasawa, A. \& Matsuzawa, T. (2010) Attacks on local persons by chimpanzees in Bossou, Republic of Guinea: long-term perspectives. American Journal of Primatology, 72, 887-896.

Hoffman, L.C. \& CAWTHORN, D.M. (2012) What is the role and contribution of meat from wildlife in providing high quality protein for consumption? Animal Frontiers, 2, 40-53.

Hoffmann, M. (2008) Thryonomys swinderianus. The IUCN Red List of Threatened Species 2008: e.T21847A9323360. Http://dx.doi.org/ 10.2305/IUCN.UK.2008.RLTS.T21847A9323360.en [accessed 14 September 2016].

Humle, T., Boesch, C., Campbell, G., Junker, J., Koops, K., Kuehl, H. \& Sop, T. (2016) Pan troglodytes ssp. verus. The IUCN Red List of Threatened Species 2016: e.T15935A17989872. [accessed 14 September 2016].

Humle, T. \& Hill, K. (2016) People-primate interactions: implications for primate conservation. In Introduction to Primate Conservation (eds S. Wich \& A. Marshall), pp. 219-240. Oxford University Press, Oxford, UK.

Humle, T. \& Matsuzawa, T. (2004) Oil palm use by adjacent communities of chimpanzees at Bossou and Nimba Mountains, West Africa. International Journal of Primatology, 25, 551-581.

InSKip, C. \& ZimmermanN, A. (2009) Human-felid conflict: a review of patterns and priorities worldwide. Oryx, 43, 18-34.

KIngDon, J. (2001) The Kingdon Field Guide to African Mammals. 4th edition. A\&C Black Publishers Ltd, London, UK.

Knight, J. (200o) Introduction. In Natural Enemies: People-Wildlife Conflicts in Anthropological Perspective (ed. J. Knight), pp. 1-35. Routledge, London, UK.

Madden, F. \& McQuinn, B. (2014) Conservation's blind spot: the case for conflict transformation in wildlife conservation. Biological Conservation, 178, 97-106.

Maxwell, S.L., Fuller, R.A., Brooks, T.M. \& Watson, J.E.M. (2016) Biodiversity: the ravages of guns, nets and bulldozers. Nature, $536,143-145$.

McLennan, M.R. (2008) Beleaguered chimpanzees in the agricultural district of Hoima, western Uganda. Primate Conservation, 23, 45-54.

McLennan, M.R. (2013) Diet and feeding ecology of chimpanzees (Pan troglodytes) in Bulindi, Uganda: foraging strategies at the forest-farm interface. International Journal of Primatology, 34, 585-614.

McLennan, M.R. \& Asimme, C. (2016) Cars kill chimpanzees: case report of a wild chimpanzee killed on a road at Bulindi, Uganda. Primates, 57, 377-388.

McLennan, M.R. \& Hill, C.M. (2010) Chimpanzee responses to researchers in a disturbed forest-farm mosaic at Bulindi, western Uganda. American Journal of Primatology, 72, 907-918.

McLennan, M.R. \& Hill, C.M. (2012) Troublesome neighbours: changing attitudes towards chimpanzees (Pan troglodytes) in a human-dominated landscape in Uganda. Journal for Nature Conservation, 20, 219-227.

McLennan, M.R. \& Hill, C.M. (2013) Ethical issues in the study and conservation of an African great ape in an unprotected, human-dominated landscape in western Uganda. In Ethics in the Field: Contemporary Challenges (eds J. MacClancy \& A. Fuentes), pp. 42-66. Bergham, New York, USA.

McLennan, M.R. \& Hockings, K.J. (2014) Wild chimpanzees show group differences in selection of agricultural crops. Scientific Reports, 4, 5956. 
McLennan, M.R. \& Hockings, K.J. (2016) The aggressive apes? Causes and contexts of great ape attacks on local persons. In Problematic Wildlife: A Cross-Disciplinary Approach (ed. F. M. Angelici), pp. 373-394. Springer International Publishing, Cham, Switzerland.

Naughton-Treves, L. (1998) Predicting patterns of crop damage by wildlife around Kibale National Park, Uganda. Conservation Biology, 12, 156-168.

Naughton-Treves, L. \& Treves, A. (2005) Socio-ecological factors shaping local support for wildlife: crop-raiding by elephants and other wildlife in Africa. In People and Wildlife: Conflict or Coexistence? (eds R. Woodroffe, S. Thirgood \& A. Rabinowitz), pp. 252-277. Cambridge University Press, Cambridge, UK.

Naughton-Treves, L., Treves, A., Chapman, C. \& Wrangham, R. (1998) Temporal patterns of crop-raiding by primates: linking food availability in croplands and adjacent forest. Journal of Applied Ecology, 35, 596-606.

OAtes, J.F. (2010) Primates of West Africa: Pocket Identification Guide. Conservation International, Arlington, USA.

Quiatt, D., Reynolds, V. \& Stokes, E.J. (2002) Snare injuries to chimpanzees (Pan troglodytes) at 10 study sites in east and west Africa. African Journal of Ecology, 40, 303-305.

Redpath, S.M., Young, J., Evely, A., Adams, W.M., Sutherland, W.J., Whitehouse, A. et al. (2013) Understanding and managing conservation conflicts. Trends in Ecology \& Evolution, 28, 100-109.

Sousa, J., Barata, A.V., Sousa, C., Casanova, C.C.N. \& Vicente, L. (2011) Chimpanzee oil-palm use in southern Cantanhez National Park, Guinea-Bissau. American Journal of Primatology, 73, 485-497.

Statistics Sierra Leone (2016) Sierra Leone 2015 Population and Housing Census (provisional results). Http://www.statistics.sl [accessed 14 September 2016].
Stiles, D., Redmond, I., Cress, D., Nellemann, C. \& Formo, R.K. (eds) (2013) Stolen Apes - The Illicit Trade in Chimpanzees, Gorillas, Bonobos and Orangutans. A Rapid Response Assessment. United Nations Environment Programme, GRID-Arendal, Arendal, Norway.

Van Vliet, N., Mertz, O., Heinimann, A., Langanke, T., Pascual, U., Schmook, B. et al. (2012) Trends, drivers and impacts of changes in swidden cultivation in tropical forest-agriculture frontiers : a global assessment. Global Environmental Change, 22, 418-429.

WebBer, A.D. \& Hill, C.M. (2014) Using participatory risk mapping (PRM) to identify and understand people's perceptions of crop loss to animals in Uganda. PLoS ONE, 9(7), e102912.

Woodroffe, R., Thirgood, S.J. \& Rabinowitz, A. (eds) (2005) People and Wildlife: Conflict or Coexistence? Cambridge University Press, Cambridge, UK.

\section{Biographical sketches}

ROSA GARRIGA is a wildlife veterinarian and conservation researcher; her work is focused on chimpanzee conservation in Sierra Leone. IGNASI MARCO is interested in wildlife ecology and diseases, with a particular interest in diseases at the human-livestock-wildlife interface. ENCARNA CASAS is a veterinarian working in wildlife management, and has an interest in animal stress evaluation. BALA AMARASEKARAN is the founder and director of the Tacugama Chimpanzee Sanctuary, and has spent the last 30 years working to protect and conserve chimpanzees and their habitats in Sierra Leone. TATYANA HUMLE is a primatologist and chimpanzee expert, who embraces an interdisciplinary approach to exploring coexistence issues between wildlife and people. 